\title{
At-Taqaddum
}

Vol. 11 No. 1 (2019) pp 1-27

DOI: http://dx.doi.org/10.21580/at.v1li1.3202

\section{DEVELOPMENT AND EFFECTIVENESS OF GEOGEBRA BASED LEARNING MEDIA REVIEWED FROM LEARNING RESULT AND SELF CONFIDENT}

\author{
Soffi Widyanesti Priwantoro ${ }^{1}$, Syariful Fahmi ${ }^{2}$ \\ ${ }^{1,2}$ Universitas Ahmad Dahlan \\ Email: ${ }^{1}$ soffiwidyanesti@pmat.uad.ac.id \\ ${ }^{2}$ Syarifulfahmi@gmail.com
}

\begin{abstract}
This study aims to develop Geogebra-based learning media in linear programing course for semester $\mathrm{V}$ students of Mathematics Education, Ahmad Dahlan University. The effectiveness of this learning media is measured based on student learning outcomes and confidence. The development model used is the borg and Gall development model that includes: (1) standard content analysis, (2) multimedia reference collection, (3) multimedia design, and (4) manufacture of GeoGebrabased learning media in the form of applets. The revision of learning media assessed by the material and learning experts, media expert, and tested on the students, both small and large classes, I,e 38 students of mathematics education university Ahmad Dahlan. Data analysis technique using questioner, observation sheet, and interview sheet. Learning media generated have good quality (B) according to the assessment of material and learning experts, media experts, and 38 students, with an average score of 209.48 from a maximum score of 260. The effectiveness of instructional media viewed from two aspects: student confidence and results learn. Geogebra-based learning media is effective regarding student self-confidence and student learning outcomes in a linear programming course.
\end{abstract}

Keywords: Learning media, Geogebra, self confident 


\section{Introduction}

The current technological development has penetrated into many fields. One area that gets attention in the use of technology is a field of education. Education is one aspect that is very important because education has an essential role in improving and developing the next generation of quality. Improving the quality of education depends heavily on a curriculum that applied to each educational institution. College, as one of the educational institution, should be able to organize quality learning activities. One of the factors that cause the low learning outcomes of students in the learning process is the use of materials that have not been by the needs of the students. A proper study should be to the needs of students, and the courses are taken ${ }^{1}$. Unfortunately, some students still think that mathematics is a stressful lesson, need more time to solve the problem and more discussing about formulas, theorems, et. which is too abstract for a student even it's a college student. ${ }^{2}$ These Presumptions aren't good beginning in learning mathematics primarily linear programming. If we let the presumption growth up in student mind it can make a negative responses in mathematics lesson even it will be effected to the lecturers. Therefore, lecturers need to do an anticipation movement to minimalize the negative perception of students into mathematics, especially linear programming.

One way of learning quality is the availability and utilization of instructional media. The position of the learning media has an essential

\footnotetext{
${ }^{1}$ Cimer, Atilla. "What makes biology learning difficult and effective: Students' views." Educational Research and Reviews 7, no. 3 (2012): 61.

${ }^{2}$ Ag, Moch Masykur, and Abdul Halim Fathani. "Mathematical Intelligence: Cara Cerdas Melatih Otak dan Menanggulangi Kesulitan Belajar." Yogyakarta: Ar-Ruгz Media (2007).
} 
role because it can ease the learning process, such as creating a learning atmosphere that is not attractive to be attractive. Media independent study in the era of technological advances urgently needed in the process of learning.

The use of computers as a medium of learning has long developed in many countries with the presence of various learning programs, even multiple studies on the success and limitations of computer use have been done in states that have used it as a medium of education. As a medium, the computer is useful for teachers as a tool in preparing teaching materials and organize learning. ${ }^{3}$ One of the frequently used learning media is learning media by using computer-based software/programs. The software on this computer can be used as a tool for interactive learning with multimedia concepts. One of the expected learning media can create an atmosphere conducive to learning and engaging is the use of multimedia applet GeoGebra. GeoGebra (www.geogebra.org) is open-source dynamic mathematics software with rapidly growing worldwide popularity, especially in Europe and North America. ${ }^{4}$ The software was conceived as Markus Hohenwarter's Master's thesis project at the University of Salzburg, Austria. The basic idea of the software development was to create a dynamic software that incorporates geometry, algebra, and calculus, which other packages treat separately (spreadsheet and computer algebra extensions are soon to be added to

\footnotetext{
${ }^{3}$ Khouyibaba, Saadia. "Teaching mathematics with technology."Procedia-Social and Behavioral Sciences 9 (2010): 638-643.

${ }^{4}$ Hohenwarter, Markus, Judith Hohenwarter, Yves Kreis, and Zsolt Lavicza. "Teaching and learning calculus with free dynamic mathematics software GeoGebra." In 11th International Congress on Mathematical Education. Monterrey, Nuevo Leon, Mexico. 2008.
} 
the software), into a single easy-to-use package. Geogebra offers a sufficient opportunity to enable students to explore various mathematical concepts. $^{5}$ Geogebra can help improve student activeness. ${ }^{6}$ When students able to be active in the learning process, then the learning activities become attractive and conducive. Geogebra can connect mathematics learning and computer so that learning mathematics will feel more fun, and students can master the subject matter quickly. One of the ideas that can be applied is to utilize computer-based media in the process of learning mathematics. The basic idea of GeoGebra's interface is to provide two presentations of each mathematical object in its algebra and graphics windows. If you change an object in one of these windows, its performance in the other one will be immediately updated. Computer algebra systems (such as Mathematica, Maple, and so on, e.g.) and dynamic geometry software (such as Geometer's Sketchpad, Cabri Geometry, and so on, e.g.) are powerful technological tools for teaching mathematics. Numerous research results suggest that these software packages can be used to encourage discovery, experimentation, and visualization in the traditional teaching of mathematics. However, researches indicated that, for the majority of teachers, the main problem

${ }^{5}$ Hohenwarter, Markus, Judith Hohenwarter, Yves Kreis, and Zsolt Lavicza. "Teaching and learning calculus with free dynamic mathematics software GeoGebra." In 11th International Congress on Mathematical Education. Monterrey, Nuevo Leon, Mexico. 2008.

${ }^{6}$ Fahmi, Syariful, and Soffi Widyanesti Priwantoro. "Pendampingan Pembuatan ELearning Dengan Moodle Yang Dipadukan Dengan Software Matematika Geogebra Untuk Guru Matematika di SMP Muhammadiyah Se-Kecamatan Godean, Sleman, Yogyakarta." AKSIOLOGIYA: Jurnal Pengabdian Kepada Masyarakat 1, no. 2 (2017): 135-141.

${ }^{7}$ Ahmad, Aminah, Tan Sin Yin, Loh Yue Fang, Yap Hui Yen, and Khoh Wee How. "Incorporating multimedia as a tool into mathematics education: A case study on diploma students in multimedia university." Procedia-Social and Behavioral Sciences 8 (2010): 594-599. 
is how to provide the technology necessary for the successful integration of technology into teaching. ${ }^{8}$

Learning media related to technology and can display moving images can make students more interactive in learning. Technology has an essential role in teaching and learning mathematics; it influences the mathematics that is taught and enhances students' learning. 'The main feature of GeoGebra is clear and easy understanding the graphical user interface, objects in GeoGebra are dynamic, marking purposes follow the mathematical syntax, etc. This is what makes Geogebra is one of the new math learning media. ${ }^{10}$ In GeoGebra, all objects can move dynamically, making it easier for students to understand the concept of math. The effectiveness of media use in learning mathematics in GeoGebra form based on achievement of used purposes. The used of learning media in mathematics learning called useful if all of the goals of using the media is reached. Otherwise, if the objectives of using learning media do not arrive yet, we can say the purposes of using the learning media is not useful. One of the functions of learning media is to decrease an abstractness of mathematics concept, make it more real so is easier to understand, make mathematic a fun and exciting lesson which can increase the academic achievement of learning mathematics and build positive thinking of mathematics lesson. In its functions, it implied the

8 Ruthven, Kenneth, Sara Hennessy, and Sue Brindley. "Teacher representations of the successful use of computer-based tools and resources in secondary-school English, mathematics and science." Teaching and Teacher Education20, no. 3 (2004): 259-275.

9 NCTM. "Principles and Standards for School Mathematics." NCTM, 2000

${ }^{10}$ Majerek, Dariusz. "Application of Geogebra for teaching mathematics." Advances in Science and Technology Research Journal 8, no. 24 (2014): 51-54. 
purposes of its use, namely to improve students mathematics learning achievements and to create a positive behavior of students through mathematics. It means the use of learning media is said to be effective if it has successfully to improve the student's mathematics achievements and build a positive behavior to mathematics. There are three things when reflecting on how students react in using technology in mathematics, namely: confidence in mathematics, confidence in using a computer, and confidence in using computers to learn mathematics. ${ }^{11}$

Multimedia whose relative use accepted by the users will increase the value of service, which is given by the institution to the students. Therefore, it is necessary to know the confidence and the behavior of users the used multimedia. There are five constructs that have been modified from the act of multimedia users with TAM (Technology Acceptance Model) model, that is the perception of users about the ease of using technology, understanding of users about the utility of multimedia, the users behavior of using multimedia, users behavior to keep using the technology, and the last frequency and user time duration of using multimedia in learning. ${ }^{12}$

In the course of linear programming sub-discussion to determine the solution of a linear program problem using graphical methods and methods of line-of-sight, it takes a media that can explain in detail the

\footnotetext{
${ }^{11}$ Fogarty, Gerry, Patricia Cretchley, Chris Harman, Nerida Ellerton, and Nissam Konki. "Validation of a questionnaire to measure mathematics confidence, computer confidence, and attitudes towards the use of technology for learning mathematics." Mathematics Education Research Journal 13, no. 2 (2001): 154-160.

${ }^{12}$ Munir. "Multimedia Konsep dan Aplikasi dalam Pendidikan.”Bandung:Alfabeta (2012).
} 
problem-solving steps linear programming. GeoGebra has the advantage of being able to show detail steps from completion using graphical methods and line of sight because, in the GeoGebra applet, all objects can move dynamically.

Linear programming is one of the subjects that must be taken by students in the Ahmad Dahlan University of mathematics education program. In this course, no lecturer provides a certain software-based learning media that facilitate students understanding the concept of solving the problem of linear programming. The use of teaching materials such as books, handouts, or student worksheets still makes the students challenging to learn linear program material. The purpose of this research is to find the problems faced by lecturers or students in the lecture of linear programming found a solution to solve the problem. So researchers use learning media in the form of applets GeoGebra to create learning media that has never made. One of the models of delivery of material in computer-based learning method is a simulation that is a computer learning model that performs learning with simulations related to the content discussed. ${ }^{13}$ Based on students skills in computer and prior knowledge about the use of GeoGebra; students can explore and rediscover ma-thematical concepts in different ways using dynamic mathematics software.

On the one hand, teachers can provide an (incomplete) interactive GeoGebra construction with accompanying questions and tasks on paper. These paper worksheets guide their students on an investigation of

\footnotetext{
${ }^{13}$ Made, Wena. "Strategi Pembelajaran Inovatif Kontemporer: Suatu Tinjauan." Konseptual Operasional. Jakarta: PT. Bumi Aksara (2009).
} 
a specific mathematical concept, assuming that they already have some experience with operating the software itself. On the other hand, teachers could also create self-contained dynamic worksheets before the lesson. With such pre-made worksheets, students don't need to operate the software GeoGebra itself but only work with an interactive HTML page in a browser. This saves the time of teaching them how to manage the software itself. Being able to customize the user interface of the integrated interactive applets (e.g. showing or hiding the algebra window, reducing the number of available tools, displaying the toolbar help), teachers can decide beforehand how much freedom or guidance they want to provide for their students and which features and tools should be available for their students. ${ }^{14}$

The construction files and dynamic worksheets described in the examples below give an overview of some basic calculus concepts that can be visualized and investigated using GeoGebra. Such compelling visualizations can support mathematical experiments, connections between symbolic and graphical representations, and discussions about conjectures and basic concepts.

Some of the above explanation makes researchers develop learning media using GeoGebra software in linear programming courses. Furthermore, interactive multimedia is expected to improve students' self-confidence in mathematics and student learning outcomes. The form of learning developed media is an applet GeoGebra.

\footnotetext{
${ }^{14}$ Hohenwarter, Markus, Judith Hohenwarter, Yves Kreis, and Zsolt Lavicza. "Teaching and learning calculus with free dynamic mathematics software GeoGebra." In 11th International Congress on Mathematical Education. Monterrey, Nuevo Leon, Mexico. 2008.
} 


\section{Method}

\section{Types of research}

This research is a research development (Research and Development), which is according to Borg \& Gall; development research is a process used to develop or validate the products used in education and learning. Borg and Gall (1989) developed detailed steps he devised in ten steps: (1) research and information collecting, (2) planning, (3) establish preliminary form of product, (4) initial field testing, (5) primary product revision, (6) main field testing, (7) operational product revision, (8) functional field testing, (9) final product revision, (10) dissemination and implementation.

\section{Research subject}

The subjects of this research trial are individuals who directly respond to product development that has been validated by one expert in mathematics education, namely Dr. Burhanudin A.N., M.Sc. and media expert, namely Rima Aksen C., M.Pd. Subjects in the trial of this product are nine students consisting of 3 students who have high classification ability, three students with medium classification capability and three students who have low classification ability. The subject of this product effectiveness research is 38 students in linear programming courses. Instrumen, which is used is manuscript of middle semester examination about linear programming and questionnaire on students confidence.

\section{Data analysis technique}

Products assessed from three things: validity, practicality, and effectiveness. The validity assessment instrument includes a material 
expert's validation sheet and a media expert's validation sheet. The instrument of practicality assessment using student response sheet to the product. Effectiveness assessment instruments used are mid-semester exam and self-confidence questionnaires of learners. The validation sheet and the practicability score sheet use the scaling scale of 5 , i.e., score 1 , score 2, score 3, score 4, and score 5. The data then converted to qualitative data by using the adaptation from Azwar (2013) as follows:

Table 1. Quantitative Data Conversion to Qualitative Data for Product's Prevalence / Practicality

\begin{tabular}{ll}
\hline Interval & Criteria \\
\hline $\mathrm{Mi}+1,5 \mathrm{Si}<\mathrm{X}$ & Very Valid/Practical \\
$\mathrm{Mi}+0,5 \mathrm{Si}<\mathrm{X} \leq \mathrm{Mi}+1,5 \mathrm{Si}$ & Valid/Practical \\
$\mathrm{Mi}-0,5 \mathrm{Si}<\mathrm{X} \leq \mathrm{Mi}+0,5 \mathrm{Si}$ & Valid/Practical \\
$\mathrm{Mi}-1,5 \mathrm{Si}<\mathrm{X} \leq \mathrm{Mi}-0,5 \mathrm{Si}$ & Less V/Practical \\
$\mathrm{X} \leq \mathrm{Mi}-1,5 \mathrm{Si}$ & No Valid/Praktical \\
\hline
\end{tabular}

Information:

$\mathrm{X}=$ total actual score

$\mathrm{Mi}=$ average ideal score $=\frac{1}{2}($ maximum score + minimum score $)$

$\mathrm{Si}=$ ideal standard deviation $=\frac{1}{6}($ maximum score - minimum score)

Learning media is said to be valid if the average score for material and media expert validation is over 176.80. The learning media of mathematics developed is said to be practical if the score of the students' assessment is more than 106.67, and the average percentage of overall learning implementation is at least $90 \%$. 
Table 2. Valid Criteria Category Media Learning

\begin{tabular}{ccc}
\hline No & Score Range & $\begin{array}{c}\text { Qualitative } \\
\text { Category }\end{array}$ \\
\hline 1 & $\bar{X}>218.41$ & Very Good \\
2 & $\mathrm{I} 76.80<\bar{X} \leq 218.41$ & Good \\
3 & $135.19<\bar{X} \leq \mathrm{I} 76.80$ & Enough \\
4 & $93.58<\bar{X} \leq 135.19$ & Bad \\
5 & $\bar{X} \leq 93.58$ & Very Bad \\
\hline
\end{tabular}

Product effectiveness regarding student learning outcomes and confidence. The instrument used to measure confidence is a questionnaire. Aspects of self-confidence (Astuti, 2017) include: (1) belief in mathematical ability; (2) firmness; (3) think realistically and rationally; and (4) positive thinking. While the instrument to determine student learning outcomes is a matter of UTS. The data of each class-tested for effectiveness by using the one-sample t-test. Type of confident data taken from students in the form of qualitative data transformed into qualitative with the provisions that can see in Table 3

Table 3. Average Interval Score Student Confidence

\begin{tabular}{ccc}
\hline No & Percentage of mastery & Qualitative Criteria \\
\hline 1 & $X>96$ & Very High
\end{tabular}




$\begin{array}{ccc}2 & 80<\mathrm{X} \leq 96 & \text { High } \\ 3 & 64<X \leq 80 & \text { Middle } \\ 4 & 48<X \leq 64 & \text { Low } \\ 5 & X \leq 48 & \text { Very Low }\end{array}$

Where $X=$ Score student confidence

The use of the product is said to be effective if the average student UTS score is more than 80 and the student confidence questionnaire score is more than 80 (high minimum criteria based on Table 3).

\section{Result and Discussion \\ Development Results}

This research has succeeded in developing Geogebra based learning media for a learner program study program for semester $\mathrm{V}$ students of Mathematics Education of Ahmad Dahlan University. Media designed in the form of applet GeoGebra.

\section{Product Trial Results}

At the design stage, conducted: (1) Curriculum Content Analysis. At this stage is done sorting linear program material that will deliver through the media of mathematics learning based on GeoGebra. The material developed in this medium is the material determining the area of completion of some linear inequalities to determine the minimum or maximum value. The material that has prepared used as the content plan of instructional media. (2) Preparation of Storyboard of instructional 
media. Storyboard of learning media prepared to simplify the making of learning media and as a reference peruses make learning media. The development of the developed storyboard based on the material to include in the learning media.

The determination of the quality of the GeoGebra applet based on the assessment of 1 material and learning expert, one media expert, and nine students on a limited trial and 38 students on a large class test. The validation instrument sheet consists of 52 statements, with 14 statements on educational aspects assessed by the material expert, 19 statements on issues of multimedia display evaluated by the media expert, and 19 indicators on the technical elements assessed by the student. While nine students on the small class test only provide valuation and input as consideration and improvement of the GeoGebra applet before being tested in the big class. The data obtained, analyzed to determine the quality of learning media. Instruments of effectiveness on large-scale trials using student self-confidence questionnaires and Mid Semester Exams (UTS). One example of the Geogebra product, which shows the area from one of the linear programming problems can be seen in picture 1 :

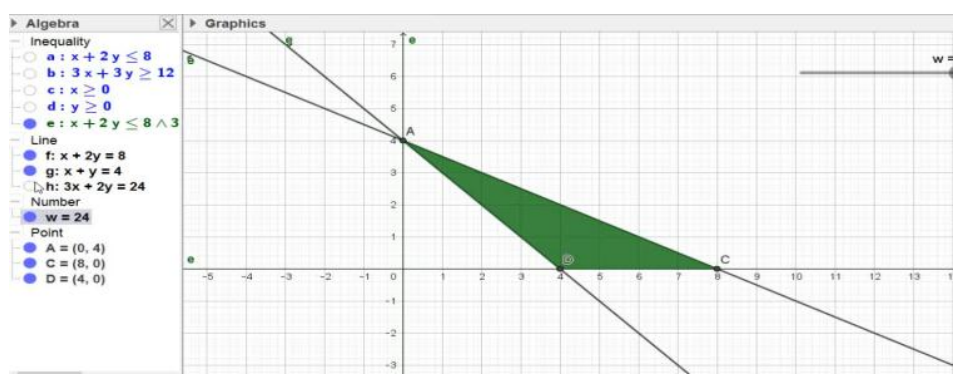

Figure 1. Example of solving linear programming 
In this picture, we can show to the students the clear area which is boarding by two lines of linear inequation. If the lecturers only draw in the whiteboard, it will take more time and not guarantee that the result of lecturer draw will be detailed, proper, and exciting.

The picture below is one of the other examples for solving a linear programming problem that doesn't have a decent area.

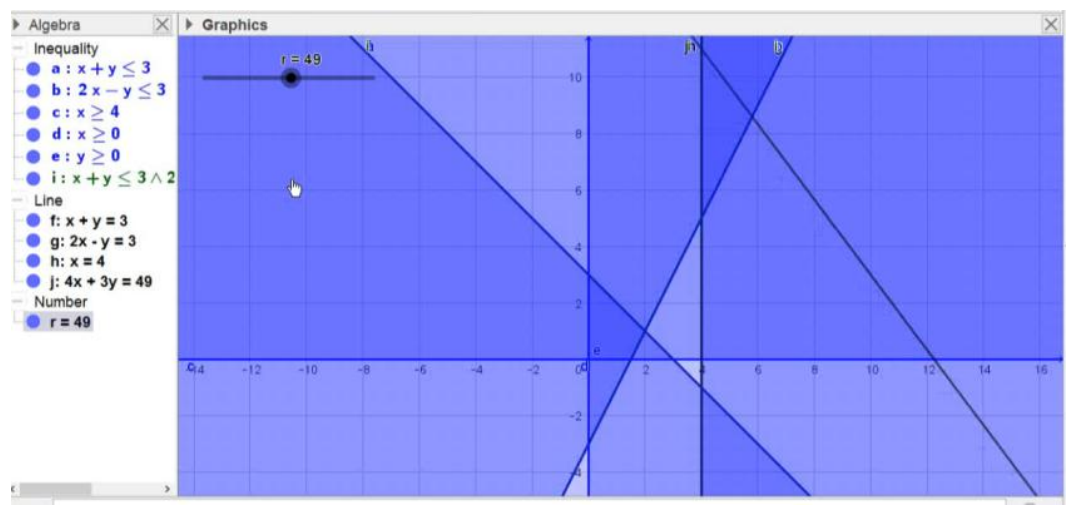

Figure 2. Example of a linear programming problem

In this picture, we can show to the students that the linear programming problem does not have a decent area, which impacts the problem can't be solved.

Based on the data analysis techniques used, the data obtained from the assessment of experts and students in the form of qualitative data transformed into a quantitative way. The resulting quantitative data is then tabulated and analyzed for each aspect of the assessment. The final score obtained, converted to the qualitative level of product validity by using the ideal scoring criteria. Based on the perfect assessment 
criteria, the quality of mathematics learning media obtained from every aspect of the assessment.

Based on the criteria of the overall ideal assessment, both the evaluation of material experts and media experts, obtained the quality of learning media based Geogebra linear program from all aspects of the valuation of 209.48. Because Average 209.48 lies between 176,80 to 218,41 , then this learning media gets a good appraisal. Overall, the media is of good quality and can be used as a learning resource in linear programming to determine the line of inquiry, available area, constraint function, optimum point, and completion by graph method.

Product effectiveness regarding student self-confidence and student learning outcomes based on UTS value. The following descriptive data of self-confidence and student learning outcomes presented.

Table 5. Descriptive Statistics of Self Confidence Score and Student Learning Outcomes

\begin{tabular}{lcc}
\multicolumn{1}{c}{ Statistics } & UTS & Self Confidence Score \\
\hline Mean & 85.83 & 91.50 \\
Std. Error of Mean & 3.96 & 2.88 \\
Std. Deviation & 9.70 & 7.06 \\
Variance & 94.17 & 49.90 \\
Minimum & 75.00 & 83.00 \\
Maximum & 100.00 & 100.00
\end{tabular}


The average student learning outcomes on UTS is 85.85 while the average student confidence score after using the learning media is 91.50 .

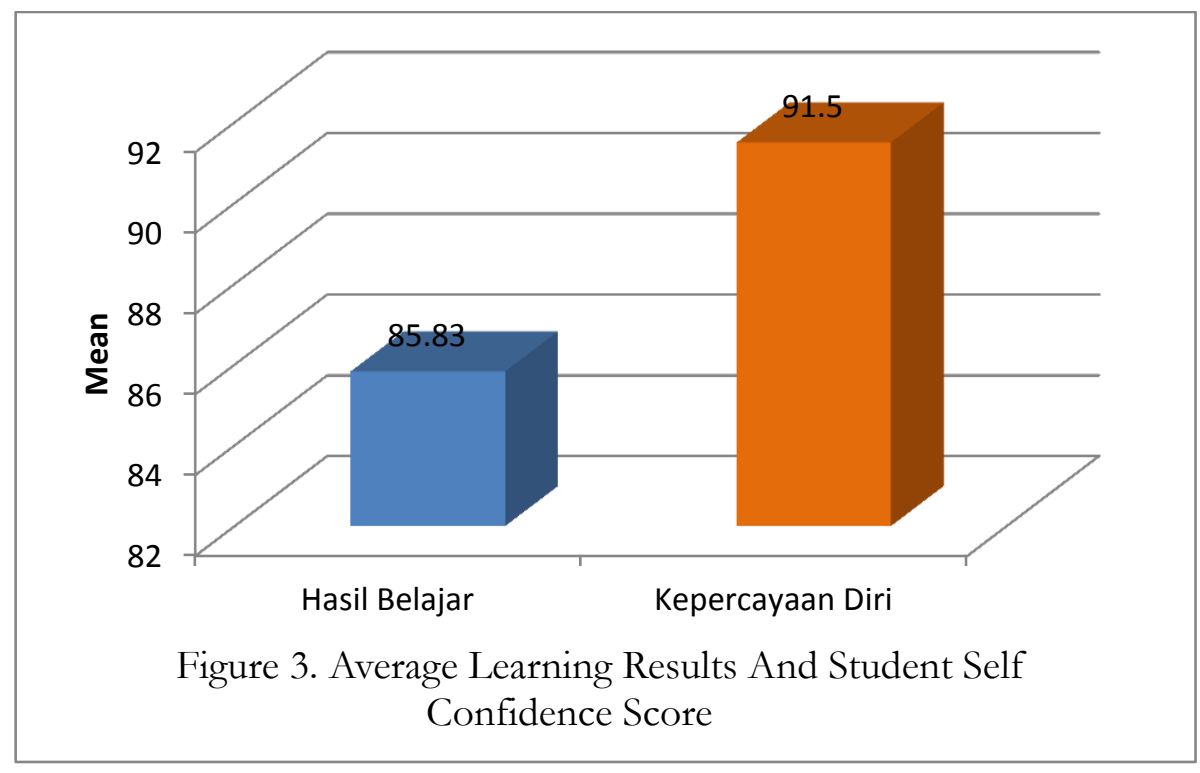

Based on the questionnaire score category, the confidence measurement results shown in figure 2 .

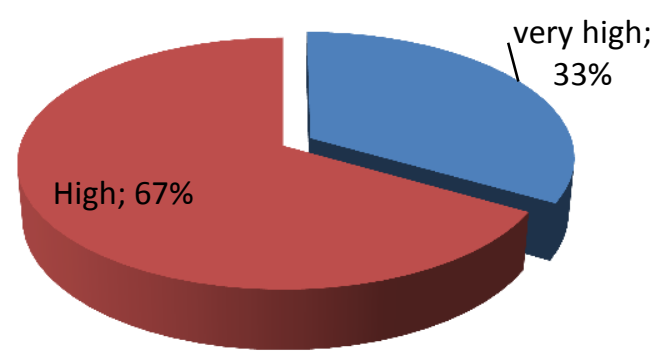

Figure 4. Percentage of Category of Student Self Confidence Score 
Based on the data above indicates that the use of learning media based on Geogebra indicates as much as 33\% of students have confidence in the category very high in learninglinear programming. While $67 \%$ of students have confidence in the top grade in learning the linear program. This suggests that the use of Geogebra-based learning media can develop student self-confidence.

Product effectiveness test regarding self-confidence done by using t-test through SPSS. Before the effectiveness test, the prerequisite test tested for normality of data. Confidence data commonly spread after normality test with Kolmogorov Smirnov test with SPSS with alpha 5\%. The result of prerequisite test significance is 0.936 (more than 0.05 ) means the data normally distributed. Then proceed with product effectiveness test regarding self-confidence with SPSS. The t-test results presented in table 6 .

Table 6. Self-Confidence t-Test Result

$$
\text { Test Value }=80
$$

\begin{tabular}{|c|c|c|c|c|c|c|}
\hline & \multirow[b]{2}{*}{$\mathrm{t}$} & \multirow[b]{2}{*}{ Df } & \multirow{2}{*}{$\begin{array}{l}\text { Sig. (2- } \\
\text { tailed) }\end{array}$} & \multirow{2}{*}{$\begin{array}{c}\text { Mean } \\
\text { Difference }\end{array}$} & \multicolumn{2}{|c|}{$\begin{array}{c}\text { 95\% Confidence Interval of the } \\
\text { Difference }\end{array}$} \\
\hline & & & & & Lower & Upper \\
\hline $\begin{array}{l}\text { Kepercayaan } \\
\text { Diri }\end{array}$ & 3.988 & 37 & .010 & 11.50000 & 4.0868 & 18.9132 \\
\hline
\end{tabular}


Based on Table 6 it found that the significance of $t$ for the confidence aspect is smaller than 0.05 . This means that the learning media based on Geogebra is effective regarding student self-confidence. Based on the results of interviews to the students, it appears there is a change in perception of linear course courses, especially in the determination of the completion of the problem and the decision of the value of optimization. Students feel more confident because, with the developed learning media, they are more satisfied with the solution of the settlement area of the linear inequality system. Determination of the corner area to determine the maximum or minimum value is more stable and confident to answer it - students confidence to a computer describing an ability to perform a task. Self-confidence affects the work ethics, determination, interest, level of difficulty from chosen purposed and the final test. ${ }^{15}$ Confidence to computer defined by the positive behavior as the result of experience and knowledge in using a computer. People who convinced that they are usually with the computer they will have the ability to understand the useful of equipment, skilled with the given task, and also able to control the output from the program in the computer. Literature shows that confidence in computer and behavior on the computer connected. ${ }^{16}$ Confidence of students and ability to master

\footnotetext{
${ }^{15}$ Palaigeorgiou, G. E., P. D. Siozos, Nikos I. Konstantakis, and Ioannis A. Tsoukalas. "A computer attitude scale for computer science freshmen and its educational implications." Journal of computer assisted learning 21, no. 5 (2005): 330-342.

${ }^{16}$ Chang, Sheeson E. "Computer anxiety and perception of task complexity in learning programming-related skills." Computers in Human Behavior 21, no. 5 (2005): 713-728.
} 
the problem is more relevant or have a connection with anxiety to the computer, than likes to the computer. ${ }^{17}$

Product effectiveness test regarding learning outcomes done by using t-test through SPSS. Before the effectiveness test, the prerequisite test tested for normality of data. Learning result data commonly spread after normality test with Kolmogorov Smirnov test with SPSS with 5\% significance level. The result of prerequisite test significance is 0.919 (more than 0.05) means the data normally distributed. Then followed by the product effectiveness test regarding learning outcomes with SPSS. The t-test results presented in the table below.

Table 7. Results of t-test based on Student Learning Result

Test Value $=75$

\begin{tabular}{|c|c|c|c|c|c|c|}
\hline & \multirow[b]{2}{*}{$\mathrm{t}$} & \multirow[b]{2}{*}{ Df } & \multirow[b]{2}{*}{ Sig. (2-tailed) } & \multirow{2}{*}{$\begin{array}{c}\text { Mean } \\
\text { Difference }\end{array}$} & \multicolumn{2}{|c|}{$\begin{array}{c}95 \% \text { Confidence } \\
\text { Interval of the } \\
\text { Difference }\end{array}$} \\
\hline & & & & & Lower & Upper \\
\hline $\begin{array}{l}\text { Hasil } \\
\text { Belajar }\end{array}$ & 2.735 & & .041 & 10.83333 & .6497 & 21.0170 \\
\hline
\end{tabular}

Based on Table 7 it found that the significance of $t$ for the learning outcomes is smaller than 0.05. This means that the learning

${ }^{17}$ Chang, Sheeson E. "Computer anxiety and perception of task complexity in learning programming-related skills." Computers in Human Behavior 21, no. 5 (2005): 713-728. 
media based on Geogebra is effective regarding student learning outcomes.

Based on the above analysis obtained the result that the learning media based on Geogebra is effective regarding self-confidence and student learning outcomes.). Research results which states that there is a positive correlation between students' self-confidence with the learning outcomes. $^{18}$

So, the suggested solution for applying technology in college math teaching is the software packet GeoGebra. The advantages of using GeoGebra are 1). In comparison to a graphing calculator, GeoGebra is more user-friendly. GeoGebra offers easy-to-use interface, multilingual menus, commands, and help. 2). GeoGebra encourages students` projects in mathematics, multiple presentations, and experimental and guided discovery learning. 3). Students can personalize their own creations through the adaptation of interface (e.g., font size, language, quality of graphics, color, coordinates, line thickness, line style, and other features). 4). GeoGebra was created to help students gain a better understanding of mathematics. Students can manipulate variables easily by merely dragging "free" objects around the plane of the drawing, or by using sliders. Students can generate changes using a technique of manipulating free objects, and then they can learn how the dependent objects will be affected. In this way, students have the opportunity to solve problems by investigating mathematical relations dynamically. 5).

${ }^{18}$ Komara, Indra Bangkit. "Hubungan antara kepercayaan diri dengan prestasi belajar dan perencanaan karir siswa." Jurnal Psikopedagogia 5, no. 1 (2016): 33-42. 
Cooperative learning is the right context for a mathematics course. ${ }^{19}$ Lecturing should be replaced by a task-oriented interactive classroom. The primary role of teaching is not to teach, explain, or otherwise attempt to "transfer" mathematical knowledge, but to create situations for students that will foster their making the necessary mental constructions. In that sense, GeoGebra provides an excellent opportunity for cooperative learning, i.e., collaborative problem-solving in Applications GeoGebra into Teaching Some Topics of Mathematics at the College Level small groups, or whole class interactive teaching, or individual/group student presentations. 6). The algebra input allows the user to generate new objects or to modify those already existing, by the command line. The worksheet files can quickly be published as Web pages. 7). GeoGebra stimulates teachers to use and assess technology in: visualization of mathematics; investigations in mathematics; interactive mathematics classes on-site or at a distance; mathematics and its applications, etc. The deficiencies of using GeoGebra are 1). Students without previous programming experience will hardly enter algebraic commands in the input box. Although the basic commands are not difficult to learn, students may feel embarrassed or quite at a loss of what to do. 2). Some methodological approaches (e.g, independent exploring and experimenting) can not be appropriate for many students. 3). In a technical sense, GeoGebra does not have in-built support for animation. So, including the modules for animating in GeoGebra should become an essential functional element for future versions. 4). Future extensions of

\footnotetext{
${ }^{19}$ Dubinsky, E., and K. Schwingendorf. "Calculus, concepts, computers and cooperative learning (C4L)." The Purdue Calculus Reform Project (2004).
} 
the software GeoGebra will surely include more characteristic features of computer algebra systems which will further increase possible complex applications in the mathematical analyses, and 3D extensions. 5). Limited research on the impact of GeoGebra in teaching and learning of mathematics.

\section{Conclusion}

The conclusion obtained is the quality of Geogebra-based learning media in linear programming courses in the excellent category, so it is feasible to be used for linear programming learning, whether in the classroom or self-study. The effectiveness of instructional media is viewed from two aspects: students' self-confidence and learning outcomes. Geogebra-based learning media is effective regarding student self-confidence and student learning outcomes in linear course courses.

\section{Acknowledgment}

We want to thank Direktorat Riset dan Pengabdian Masyarakat (DRPM) from Kementerian RistekDikti for funding this research through the "skim hibah dosen pemula" program.

\section{References}

Ag, Moch Masykur, and Abdul Halim Fathani. "Mathematical Intelligence: Cara Cerdas Melatih Otak dan Menanggulangi Kesulitan Belajar." Yogyakarta: Ar-Ruгz Media (2007).

Agnew, Palmer W., Anne S. Kellerman, and Jeanine Meyer.Multimedia in the Classroom. Allyn and Bacon, 1996.145-25.

Ahmad, Aminah, Tan Sin Yin, Loh Yue Fang, Yap Hui Yen, and Khoh Wee How. "Incorporating multimedia as a tool into mathematics 
education: A case study on diploma students in multimedia university." Procedia-Social and Behavioral Sciences 8 (2010): 594-599.

Bell, Frederick H. Teaching and learning mathematics (in secondary schools). WC Brown Company, 1978.195-50

Berger, Emil J. "Instructional Aids in Mathematics. National Council of Teachers of Mathematics Yearbook 34." (1973).

Bernard, H. Russell, and Harvey Russell Bernard. Social research methods: Qualitative and quantitative approaches. Sage, 2013.

Berwick, Robert C., and Noam Chomsky. Why only us: Language and evolution. MIT press, 2016.

Borg, W.R. dan Gall, M.D., Educational Number: an Introduction, forth edition ( New York: Longman, 1983), 167-78

Chang, Sheeson E. "Computer anxiety and perception of task complexity in learning programming-related skills." Computers in Human Behavior 21, no. 5 (2005): 713-728.

Cimer, Atilla. "What makes biology learning difficult and effective: Students' views." Educational Research and Reviews 7, no. 3 (2012): 61. Cretchley, Patricia, and Peter Galbraith. "Mathematics, computers and umbilical cords." New Zealand Journal of Mathematics 32, no. Supple (2003): $37-46$.

Dubinsky, E., and K. Schwingendorf. "Calculus, concepts, computers and cooperative learning (C4L)." The Purdue Calculus Reform Project (2004).

El-Wakil, Ahmed. "The Prophet's Treaty with the Christians of Najran: An Analytical Study to Determine the Authenticity of the Covenants." Journal of Islamic Studies 27, no. 3 (2016): 273-354 
Fahmi, Syariful, and Soffi Widyanesti Priwantoro. "Pendampingan Pembuatan E-Learning Dengan Moodle Yang Dipadukan Dengan Software Matematika Geogebra Untuk Guru Matematika di SMP Muhammadiyah Se-Kecamatan Godean, Sleman, Yogyakarta." AKSIOLOGIYA: Jurnal Pengabdian Kepada Masyarakat 1, no. 2 (2017): 135-141.

Fogarty, Gerry, Patricia Cretchley, Chris Harman, Nerida Ellerton, and Nissam Konki. "Validation of a questionnaire to measure mathematics confidence, computer confidence, and attitudes towards the use of technology for learning mathematics." Mathematics Education Research Journal 13, no. 2 (2001): 154-160.

Geisert, Paul G., and Mynga K. Futrell. Teachers, computers, and curriculum: Microcomputers in the classroom. Allyn \& Bacon, Inc., 1999.197-36

Gunawan, Dedi. "Modul Pembelajaran Interaktif Elektronika Dasar Untuk Program Keahlian Teknik Audio Video Smk Muhammadiyah 1 Sukoharjo Menggunakan Macromedia Flash 8." (2010).

Heinich, Robert. Instructional media and technologies for learning. Simon \& Schuster Books For Young Readers, 1996.

Hohenwarter, Markus, Judith Hohenwarter, Yves Kreis, and Zsolt Lavicza. "Teaching and learning calculus with free dynamic mathematics software GeoGebra." In 11th International Congress on Mathematical Education. Monterrey, Nuevo Leon, Mexico. 2008.

Jain, Sachin, and Martin Dowson. "Mathematics anxiety as a function of multidimensional self-regulation and self-efficacy."Contemporary Educational Psychology 34, no. 3 (2009): 240-249 
James \& James. Mathematic dictionary $\left(4^{\text {th }}\right.$ ed). New York: Van Nonstrand Reinhold. 1976.

Kemp, Jerrold E., and Deane K. Dayton. Planning and producing instructional media. Harper \& Row, 1985.

Khambari, Mas Nida Md, Wong Su Luan, and Ahmad Fauzi Mohd Ayub. "Technology in Mathematics teaching: The pros and cons." Procedia-Social and Behavioral Sciences 8 (2010): 555-560.

Khouyibaba, Saadia. "Teaching mathematics with technology."ProcediaSocial and Behavioral Sciences 9 (2010): 638-643.

Komara, Indra Bangkit. "Hubungan antara kepercayaan diri dengan prestasi belajar dan perencanaan karir siswa." Jurnal Psikopedagogia 5, no. 1 (2016): 33-42.

Laubscher, Dorothy Joy. "Mathematics teacher-students attitude towards information and communication technology across three countries." PhD diss., North-West University, 2010.

Macalister, John, and I. S. P. Nation. Language curriculum design. Routledge, 2009.

Made, Wena. "Strategi Pembelajaran Inovatif Kontemporer: Suatu Tinjauan." Konseptual Operasional. Jakarta: PT. Bumi Aksara (2009).

Majerek, Dariusz. "Application of Geogebra for teaching mathematics." Advances in Science and Technology Research Journal 8, no. 24 (2014): 51-54.

Munir. "Multimedia Konsep dan Aplikasi dalam Pendidikan."Bandung:Alfabeta (2012). 
Nazeri. "Penggunaan E-Flipbook dalam Topic Elektrik Dan Elektronik: Inovasi Dalam Penggunaan Bentuk dan Teknologi PISMP RBT”. Prosiding seminar penyelidikan IPG Zon Timur.

NCTM. "Principles and Standards for School Mathematics." NCTM, 2000

Nisiyatussani, Nisiyatussani, Vidya Ayuningtyas, Maman Fathurrohman, and Nurul Anriani. "GeoGebra applets design and development for junior high school students to learn quadrilateral mathematics concepts." Journal on Mathematics Education 9, no. 1 (2018): 27-40.

Palaigeorgiou, G. E., P. D. Siozos, Nikos I. Konstantakis, and Ioannis A. Tsoukalas. "A computer attitude scale for computer science freshmen and its educational implications." Journal of computer assisted learning 21, no. 5 (2005): 330-342.

Pietersen, J., and K. Maree. "Overview of statistical techniques." First steps in research (2007): 215-252.

Ramdania, Diena Randa. "Penggunaan Media Flash Flip Book Dalam Pembelajaran Teknologi Informasi Dan Komunikasi Untuk Meningkatkan Hasil Belajar Siswa."Bandung. UPI. Artikel Ilmiah Tugas Akbir (2013).

Ruthven, Kenneth, Sara Hennessy, and Sue Brindley. "Teacher representations of the successful use of computer-based tools and resources in secondary-school English, mathematics and science." Teaching and Teacher Education20, no. 3 (2004): 259-275.

Sakat, Ahamad Asmadi, Mohamad Zaid Mohd Zin, Rusli Muhamad, Anzaruddin Ahmad, Nurfahiratul Azlina Ahmad, and Mohd Arip Kasmo. "Educational technology media method in teaching and 
learning progress." American Journal of Applied Sciences 9, no. 6 (2012): 874-878.

Suryabrata, Sumadi. Psikologi pendidikan. PT Rajagrafindo, 2005.

William, K. B \& Sawyer, C. S, Using information technology. (Terjemahan Nur Wijayaning Rahayu \& Arie Prabawati). McGraw Hill, 2007 